\title{
KESALAHAN SISWA SMP KELAS VII DALAM MENYELESAIKAN SOAL OPERASI BENTUK ALJABAR
}

\author{
Atik Sundari $^{1}$, Masri $^{2}$ \\ FKIP Universitas Muhammadiyah Bengkulu ${ }^{1,2}$ \\ atiksundari27@gmail.com ${ }^{1}$
}

\begin{abstract}
ABSTRAK
Penelitian ini bertujuan untuk mendeskripsikan kesalahan yang dilakukan siswa dalam menyelesaikan soal matematika pada topik operasi bentuk aljabar. Jenisjenis kesalahan berupa kesalahan fakta, kesalahan konsep, kesalahan prinsip, dan kesalahan operasi. Data yang digunakan dalam penelitian ini berasal dari hasil tes siswa dalam menyelesaikan soal matematika topik operasi bentuk aljabar. Subjek penelitian ini adalah 9 orang siswa kelas VII SMP Negeri 21 Kota Bengkulu. Penelitian dilaksanakan pada bulan Juli 2020. Data dianalisis secara deskriptif kualitatif. Hasil dari penelitian ini, kesalahan-kesalahan yang ditemukan pada siswa kelas VII dalam mengerjakan soal matematika pada topik operasi bentuk aljabar adalah kesalahan teorema atau definisi, kesalahan data, dan kesalahan teknis. Jenis kesalahan yang banyak dilakukan siswa adalah jenis kesalahan teorema atau definisi dan kesalahan teknis.
\end{abstract}

Kata kunci : kesalahan, operasi, bentuk aljabar

\begin{abstract}
The purpose of this study is to describe the errors made by students when solving algebraic operations math problems. Factual errors, conceptual errors, principle errors, and operating errors are the four types of errors. The data for this study came from the results of student tests in which they solved algebraic operations math problems. The subjects of this study were nine seventh-grade students from SMP Negeri 21 Bengkulu City. The research was carried out in July 2020. The information was analyzed both descriptively and qualitatively. According to the findings of this study, the errors found in class VII students working on algebraic operations math problems were theorem or definition errors, data errors, and technical errors. Many students commit theorem or definition errors, as well as technical errors.
\end{abstract}

Keywords : error, operation, algebraic form

\section{PENDAHULUAN}

Pembelajaran di sekolah merupakan suatu proses penyampaian informasi atau pengetahuan dari guru kepada siswa guna membimbing siswa untuk memperoleh dan memproses informasi atau pengetahuan sehingga tercipta perubahan yang lebih baik. Komalasari (2013) mengatakan pembelajaran suatu sistem atau suatu proses membelajarkan yang direncanakan, dilaksanakan, dievaluasi secara sistematis agar pembelajar dapat mencapai tujuan-tujuan pembelajaran secara efektif dan efisien. 
Demikian halnya dengan pembelajaran matematika yang tentunya memiliki karakteristik tersendiri dengan cirinya sebagai salah satu ilmu pasti.

Pembelajaran matematika diharapkan mampu menciptakan siswa yang memiliki pola pikir yang logis, disiplin dan kritis serta terampil dalam kehidupan sehari-hari (Setiawan, 2011). Matematika merupakan salah satu pengetahuan yang mempunyai manfaat yang sangat besar dalam kehidupan sehari-hari, serta matematika juga merupakan salah satu pembelajaran yang diberikan kepada semua peserta didik (BNSP, 2006; Kamarullah, 2017; Mustikasari et al., 2017; Astini dan Purwati, 2020). Namun untuk mencapai hal tersebut bukanlah hal yang mudah karena materi matematika harus dikuasai oleh peserta didik tidak berhenti pada satu titik saja.

Matematika adalah ilmu dasar untuk membantu memahami ilmu pengetahuan yang lain (Fidayanti, Shodiqin, dan Suyitno, 2020). Oleh sebab itu, matematika sangatlah penting untuk dipelajari dan dipahami. Matematika yang bersifat abstrak membuat siswa menjadi merasa kesulitan memahaminya (Arigiyati, 2017). Banyak siswa yang menganggap matematika itu sulit sehingga menyebabkan matematika menjadi mata pelajaran yang ditakuti dan dijauhi siswa (Kompasiana, 2014). Padahal, matematika dipelajari pada setiap jenjang pendidikan dan menjadi salah satu pengukur (indikator) keberhasilan siswa dalam menempuh satu jenjang pendidikan, serta menjadi materi ujian untuk seleksi penerimaan menjadi tenaga kerja bidang tertentu.

Berdasarkan pengamatan terhadap hasil penyelesaian soal matematika topik operasi bentuk aljabar, banyak ditemukan kesalahan siswa dalam menyelesaikan soal operasi bentuk aljabar. Setelah diidentifikasi siswa belum terampil dalam operasi hitung bentuk aljabar. Hal ini disebabkan oleh siswa kurang berlatih dalam mengerjakan soal-soal operasi bentuk aljabar. Selain itu, siswa masih belum memahami definisi dari variabel, konstanta, dan koefisien sehingga mengakibatkan kesalahan ketika mengerjakan soal yang berkaitan dengan variabel, koefisien dan konstanta.

Letak kesalahan siswa dapat diketahui dengan diberikannya tes. Penting adanya analisis kesalahan siswa untuk mengetahui letak kesalahan yang dilakukan siswa dalam mengerjakan soal. Dengan demikian guru dapat memberikan tindakan yang tepat untuk mengurangi kesalahan oleh siswa.

Materi operasi bentuk aljabar dipilih karena materi ini merupakan materi prasyarat untuk menuju materi selanjutnya. Karena pentingnya materi ini, maka siswa harus benar-benar menguasai materi ini untuk dapat mempelajari materi berikutnya.

Berdasarkan paparan tersebut, maka perlu diadakan penelitian yang bertujuan mengetahui kesalahan apa saja yang dilakukan siswa kelas VII SMP Negeri 21 Kota Bengkulu dalam menyelesaikan soal operasi bentuk aljabar. Melalui penyelidikan terhadap penyimpangan-penyimpangan yang dilakukan siswa dalam mengerjakan soal matematika pada topik operasi bentuk aljabar, maka akan diketahui jenis kesalahan yang dilakukannya. 


\section{METODE}

Jenis penelitian ini merupakan deskriptif kualitatif yaitu berusaha mendeskripsikan suatu gejala atau kejadian yang menjadi fokus perhatian yang dijabarkan sebagaimana adanya dengan tanpa menggunakan pendekatan angka. Penelitian ini bertujuan mendeskripsikan kesalahan yang dilakukan siswa dalam menyelesaikan soal operasi bentuk aljabar.

Penelitian ini dilaksanakan pada bulan Juli 2020. Subjek penelitian diambil 9 orang yang merupakan siswa kelas VII SMP Negeri 21 Kota Bengkulu. Data yang digunakan berupa data tertulis yang berasal dari hasil tes siswa dalam menyelesaikan soal operasi bentuk aljabar. Pada saat penelitian, siswa telah selesai mempelajari materi tersebut. Tes diberikan untuk memperoleh data mengenai kesalahan siswa dalam menyelesaikan soal operasi bentuk aljabar.

Kesalahan siswa dalam menyelesaikan soal tersebut dianalisis secara deskriptif. Analisis data dalam penelitian kualitatif meliputi reduksi data, penyajian data, verifikasi dan menarik kesimpulan. Mereduksi data berarti merangkum, memilih hal-hal yang pokok, memfokuskan pada hal-hal yang penting, dicari tema dan polanya. Dengan demikian data yang telah direduksi akan memberikan gambaran yang lebih jelas, dan mempermudah dilakukannya pengumpulan data (Sugiyono, 2013). Adapun tahap reduksi data dalam penelitian ini sebagai berikut :

(1) Mengoreksi hasil pekerjaan siswa yang kemudian dirangking untuk menentukan siswa yang akan dijadikan objek penelitian.

(2) Hasil pekerjaan siswa yang menjadi subjek penelitian merupakan data mentah kemudian ditransformasikan ke dalam catatan.

Penyajian data dilakukan dengan memunculkan kumpulan data yang sudah terorganisir dan terkategori yang memungkinkan dilakukan penarikan kesimpulan. Dalam penelitian kualitatif, penyajian data bisa dilakukan dalam bentuk uraian singkat, bagan, hubungan antar kategori, flowchart, dan sejenisnya (Sugiono, 2013). Penyajian data yang paling sering digunakan untuk menyajikan data dalam penelitian kualitatif adalah dengan teks yang bersifat naratif. Tahap penyajian data dalam penelitian ini adalah menyajikan hasil pekerjaan siswa yang dipilih sebagai subjek penelitian. Melalui penyajian data tersebut, maka akan terorganisasikan, tersusun dalam pola hubungan, sehingga mudah dipahami apa yang terjadi dan mampu menjawab permasalahan dalam penelitian ini.

Verifikasi data. Pengambilan subjek penelitian didasarkan pada siswa yang melakukan kesalahan dari hasil tes. Dipilih 9 orang siswa kelas VII sebagai subjek penelitian. Langkah pertama yang dilakukan untuk menentukan subjek penelitian adalah hasil pekerjaan siswa dikoreksi kemudian diurutkan berdasarkan skornya yaitu dari skor terbesar ke yang terkecil. Skor siswa yang telah diurutkan tadi kemudian diambil sebagai subjek penelitian. Cara pengambilan subjek penelitian dengan memilih siswa dengan skor terendah, apabila terdapat siswa dengan skor nilai sama maka dipilih siswa dengan hasil pekerjaan yang lebih banyak uraiannya.

Menarik kesimpulan didapat dari analisis hasil pekerjaan siswa yang menjadi subjek penelitian sehingga dapat diketahui letak dan penyebab kesalahan siswa dalam menyelesaikan soal operasi bentuk aljabar. 


\section{HASIL DAN PEMBAHASAN}

Berikut ini adalah hasil analisis kesalahan dari 9 siswa kelas VII SMP Negeri 21 Kota Bengkulu dalam mengerjakan soal-soal dengan topik operasi bentuk aljabar.

\section{Kasus S1}

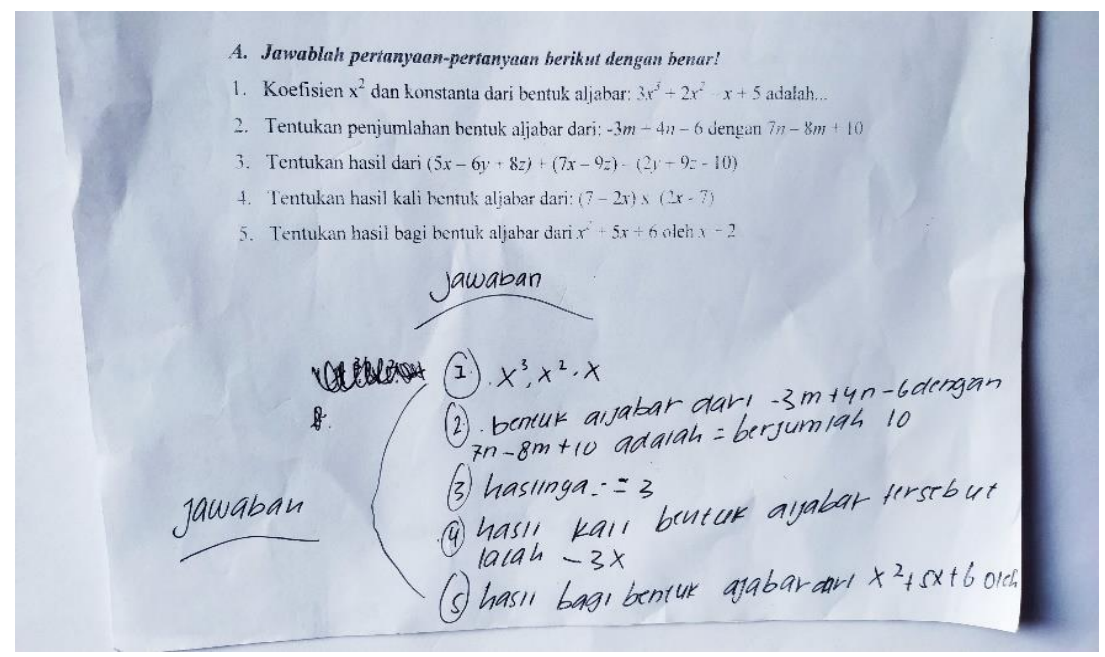

Gambar 1. Kesalahan S1 dalam mengerjakan soal tes

Hasil analisis dari jawaban S1 pada gambar 1 bahwasanya S1 kurang memahami teorema atau definisi konsep operasi bentuk aljabar dari tes yang diberikan.

Tabel 1. Kesalahan dan penyebabnya pada kasus S1

\begin{tabular}{|c|c|c|}
\hline $\begin{array}{l}\text { No. } \\
\text { Soal }\end{array}$ & Kesalahan & Indikasi kesalahan \\
\hline \multirow[t]{2}{*}{1} & $\begin{array}{l}\text { tidak memahami teorema atau } \\
\text { definisi koefisien dan konstanta }\end{array}$ & $\begin{array}{l}\text { kurangnya pemahaman tentang definisi } \\
\text { koefisien, variabel dan konstanta dalam } \\
\text { operasi bentuk aljabar }\end{array}$ \\
\hline & tidak memahami maksud soal & menjawab soal dengan asal-asalan \\
\hline \multirow[t]{2}{*}{2} & $\begin{array}{l}\text { tidak memahami operasi } \\
\text { penjumlahan bentuk aljabar }\end{array}$ & $\begin{array}{l}\text { tidak mampu menyelesaikan soal } \\
\text { penjumlahan operasi bentuk aljabar }\end{array}$ \\
\hline & $\begin{array}{l}\text { salah dalam memahami maksud } \\
\text { soal }\end{array}$ & $\begin{array}{l}\text { menganggap semua suku dalam bentuk } \\
\text { aljabar dapat langsung dioperasikan } \\
\text { tanpa mengelompokkan suku-suku yang } \\
\text { sama. }\end{array}$ \\
\hline \multirow[t]{3}{*}{3.} & $\begin{array}{l}\text { tidak mengganggap variabel } \mathrm{x} \text {, } \\
\mathrm{y}, \mathrm{z} \text { berpengaruh dalam operasi } \\
\text { bentuk aljabar }\end{array}$ & $\begin{array}{l}\text { mengerjakan soal tanpa pengelompokan } \\
\text { sesuai dengan suku-suku yang memiliki } \\
\text { variabel sama }\end{array}$ \\
\hline & $\begin{array}{l}\text { tidak menguasai operasi bentuk } \\
\text { aljabar terutama penjumlahan } \\
\text { dan pengurangan }\end{array}$ & $\begin{array}{l}\text { tidak mampu menyelesaikan soal } \\
\text { penjumlahan dan pengurangan dalam } \\
\text { operasi bentuk aljabar }\end{array}$ \\
\hline & kesalahan teknis & $\begin{array}{l}\text { memiliki hasil jawaban tetapi tidak } \\
\text { memiliki proses pencapaian hasil }\end{array}$ \\
\hline \multirow[t]{2}{*}{4.} & $\begin{array}{l}\text { salah dalam memahami maksud } \\
\text { soal }\end{array}$ & $\begin{array}{l}\text { tidak menguasai operasi bentuk aljabar } \\
\text { terutama perkalian bentuk aljabar }\end{array}$ \\
\hline & kesalahan teknis & $\begin{array}{l}\text { memiliki hasil jawaban tetapi tidak } \\
\text { memiliki proses pencapaian hasil }\end{array}$ \\
\hline
\end{tabular}



5. kesalahan teknis
tidak menjawab soal tes

\section{Kasus S2}

A. Jawablah pertanyaan-pertanyaan berikut dengan benar?

(1) Koefisien $x^{2}$ dan konstanta dari bentuk aljabar: $3 x^{3}+2 x^{2}-x+5$ adalah

(2) Tentukan penjumlahan bentuk aljabar dari: $-3 m+4 n-6$ dengan $7 n-8 m+10$

(3) Tentukan hasil dari $(5 x-6 y+8 z)+(7 x-9 z)-(2 y+9 z-10)$

(7) Tentukan hasil kali bentuk aljabar dari: $(7-2 x) \times(2 x-7$

(5) Tentukan hasil bagi bentuk aljabar dari $x^{2}+5 x+6$ oleh $x+2$

jawab

1. $2 x^{2}$ dun 5

2. $11 m+11 n+4 \quad 5$

3. $12 x^{2}+56 \rightarrow-8 z$

$414 x-(-49) \times 4 \times 2-14 x$

$5 x^{2}+2 x+8 x$

$=x^{2}+10 x^{2}$

Gambar 2. Kesalahan S2 dalam mengerjakan soal tes

Hasil analisis dari jawaban S2 pada gambar 2 bahwasanya S2 menjawab soal tes tanpa melalui proses pengerjaan soal, yang artinya dianggap S2 mendapat jawaban dari mencontek atau menyalin jawaban.

Tabel 2. Kesalahan dan penyebabnya pada kasus S2

\begin{tabular}{cll}
\hline $\begin{array}{c}\text { No. } \\
\text { Soal }\end{array}$ & \multicolumn{1}{c}{ Kesalahan } & \multicolumn{2}{c}{ Indikasi kesalahan } \\
\hline 2 & kesalahan teknis & $\begin{array}{l}\text { memiliki hasil jawaban tetapi tidak } \\
\text { memiliki proses pencapaian hasil }\end{array}$ \\
\hline 3 & $\begin{array}{l}\text { salah dalam memahami maksud } \\
\text { soal }\end{array}$ & $\begin{array}{l}\text { tidak menguasai operasi bentuk aljabar } \\
\text { terutama penjumlahan dan pengurangan }\end{array}$ \\
\cline { 2 - 4 } & kesalahan teknis & $\begin{array}{l}\text { memiliki hasil jawaban tetapi tidak } \\
\text { memiliki proses pencapaian hasil }\end{array}$ \\
\hline 4 & salah dalam memahami maksud & $\begin{array}{l}\text { tidak menguasai operasi bentuk aljabar } \\
\text { terutama perkalian }\end{array}$ \\
\cline { 2 - 4 } & keal & $\begin{array}{l}\text { memiliki hasil jawaban tetapi tidak } \\
\text { memiliki proses pencapaian hasil }\end{array}$ \\
\hline 5 & kesalahan teknis & $\begin{array}{l}\text { memiliki hasil jawaban tetapi tidak } \\
\text { memiliki proses pencapaian hasil }\end{array}$ \\
\hline
\end{tabular}




\section{Kasus S3}

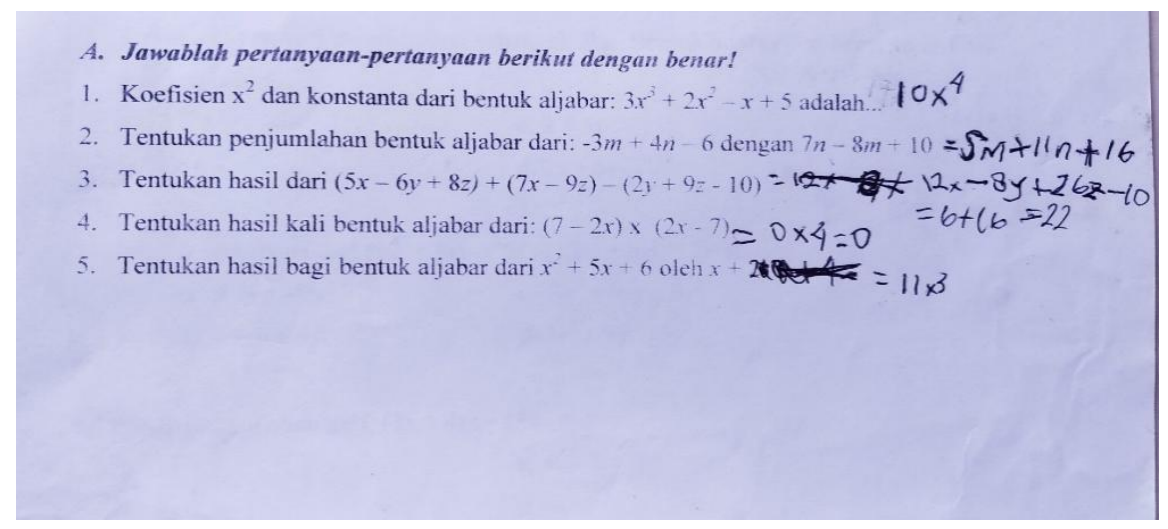

Gambar 3. Kesalahan S3 dalam mengerjakan soal tes

Hasil analisis dari jawaban S3 pada gambar 3 bahwasanya koefisien dan konstanta adalah suatu yang harus dicari nilainya. Seperti pada soal tes nomor 1, S3 mencari nilai koefisien dan konstanta yang diminta.

Tabel 3. Kesalahan dan penyebabnya pada kasus S3

\begin{tabular}{|c|c|c|}
\hline $\begin{array}{l}\text { No. } \\
\text { Soal }\end{array}$ & Kesalahan & Indikasi kesalahan \\
\hline \multirow[t]{3}{*}{1} & $\begin{array}{l}\text { tidak memahami teorema atau } \\
\text { definisi koefisien dan konstanta }\end{array}$ & $\begin{array}{l}\text { kurangnya pemahaman tentang definisi } \\
\text { koefisien, variabel dan konstanta dalam } \\
\text { operasi bentuk aljabar }\end{array}$ \\
\hline & $\begin{array}{l}\text { salah dalam memahami maksud } \\
\text { soal }\end{array}$ & tidak menguasai operasi bentuk aljabar \\
\hline & kesalahan teknis & $\begin{array}{l}\text { menganggap koefisien dan konstanta } \\
\text { merupakan suatu yang harus dicari } \\
\text { nilainya }\end{array}$ \\
\hline \multirow[t]{2}{*}{2} & $\begin{array}{l}\text { salah dalam memahami maksud } \\
\text { soal }\end{array}$ & $\begin{array}{l}\text { tidak menguasai operasi bentuk aljabar } \\
\text { terutama penjumlahan }\end{array}$ \\
\hline & kesalahan teknis & $\begin{array}{l}\text { memiliki hasil jawaban tetapi tidak } \\
\text { memiliki proses pencapaian hasil }\end{array}$ \\
\hline \multirow[t]{2}{*}{3} & kesalahan teknis & $\begin{array}{l}\text { memiliki hasil jawaban tetapi tidak } \\
\text { memiliki proses pencapaian hasil }\end{array}$ \\
\hline & kesalahan data & $\begin{array}{l}\text { menganggap variabel setiap suku adalah } \\
\text { sama } \\
12 x-8 y+26 z-10=6+16=22\end{array}$ \\
\hline \multirow[t]{3}{*}{4} & kesalahan teknis & $\begin{array}{l}\text { memiliki hasil jawaban tetapi tidak } \\
\text { memiliki proses pencapaian hasil }\end{array}$ \\
\hline & $\begin{array}{l}\text { salah dalam memahami maksud } \\
\text { soal }\end{array}$ & $\begin{array}{l}\text { tidak menguasai operasi bentuk aljabar } \\
\text { terutama perkalian }\end{array}$ \\
\hline & kesalahan teorema atau definisi & $\begin{array}{l}\text { asal menjawab tanpa mengetahui } \\
\text { maksud dari soal tes }\end{array}$ \\
\hline \multirow[t]{2}{*}{5} & kesalahan teknis & $\begin{array}{l}\text { memiliki hasil jawaban tetapi tidak } \\
\text { memiliki proses pencapaian hasil }\end{array}$ \\
\hline & kesalahan teorema atau definisi & $\begin{array}{l}\text { asal menjawab tanpa mengetahui } \\
\text { maksud dari soal tes }\end{array}$ \\
\hline
\end{tabular}




\section{Kasus S4}

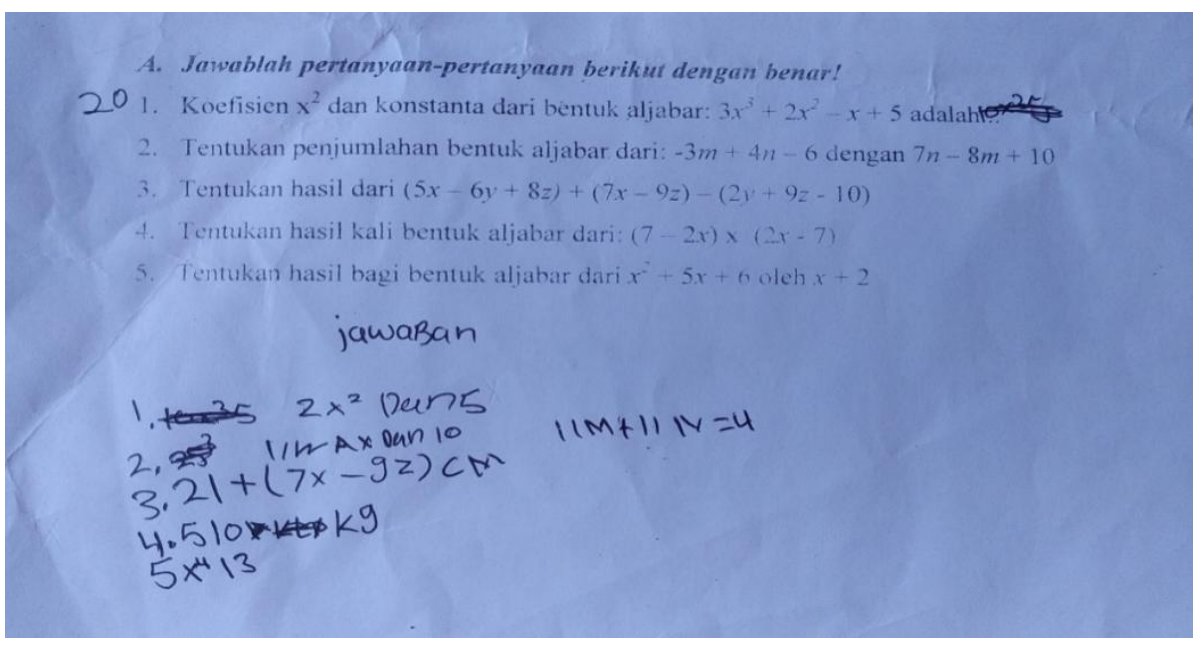

Gambar 4. Kesalahan S4 dalam mengerjakan soal tes

Hasil analisis dari jawaban S4 pada gambar 4 bahwasanya jawaban S4 sama seperti S2 yakni tidak memiliki proses untuk mendapatkan hasil jawaban.

Tabel 4. Kesalahan dan penyebabnya pada kasus S4

\begin{tabular}{|c|c|c|}
\hline $\begin{array}{l}\text { No. } \\
\text { Soal }\end{array}$ & Kesalahan & Indikasi kesalahan \\
\hline \multirow[t]{3}{*}{2.} & kesalahan teknis & $\begin{array}{l}\text { memiliki hasil jawaban tetapi tidak } \\
\text { memiliki proses pencapaian hasil }\end{array}$ \\
\hline & $\begin{array}{l}\text { salah dalam memahami maksud } \\
\text { soal }\end{array}$ & $\begin{array}{l}\text { tidak menguasai operasi bentuk aljabar } \\
\text { terutama penjumlahan dan pengurangan }\end{array}$ \\
\hline & kesalahan data & jawabannya susah untuk dimengerti \\
\hline \multirow[t]{3}{*}{3.} & $\begin{array}{l}\text { salah dalam memahami maksud } \\
\text { soal }\end{array}$ & $\begin{array}{l}\text { tidak menguasai operasi bentuk aljabar } \\
\text { terutama penjumlahan dan pengurangan }\end{array}$ \\
\hline & kesalahan teknis & $\begin{array}{l}\text { memiliki hasil jawaban tetapi tidak } \\
\text { memiliki proses pencapaian hasil }\end{array}$ \\
\hline & kesalahan data & $\begin{array}{l}\text { jawabannya susah untuk dimengerti. } \\
21+(7 \mathrm{x}-9 \mathrm{z}) \mathrm{CM} \\
\text { terlalu memaksa menjawab }\end{array}$ \\
\hline \multirow[t]{3}{*}{4.} & kesalahan teknis & $\begin{array}{l}\text { memiliki hasil jawaban tetapi tidak } \\
\text { memiliki proses pencapaian hasil }\end{array}$ \\
\hline & kesalahan data & $\begin{array}{l}\text { asal menjawab tanpa mengetahui } \\
\text { maksud dari soal tes } \\
(510 \mathrm{k} 9) \\
\text { terlalu memaksa menjawab soal }\end{array}$ \\
\hline & $\begin{array}{l}\text { salah dalam memahami maksud } \\
\text { soal }\end{array}$ & $\begin{array}{l}\text { tidak menguasai operasi bentuk aljabar } \\
\text { terutama perkalian }\end{array}$ \\
\hline \multirow[t]{2}{*}{5.} & kesalahan teknis & $\begin{array}{l}\text { memiliki hasil jawaban tetapi tidak } \\
\text { memiliki proses pencapaian hasil }\end{array}$ \\
\hline & kesalahan data & $\begin{array}{l}\text { asal menjawab tanpa mengetahui } \\
\text { maksud dari soal tes } \\
\left(\mathrm{x}^{4} 13\right) \\
\text { terlalu memaksa menjawab soal }\end{array}$ \\
\hline
\end{tabular}


salah dalam memahami maksud tidak menguasai operasi bentuk aljabar soal terutama pembagian

\section{Kasus S5}

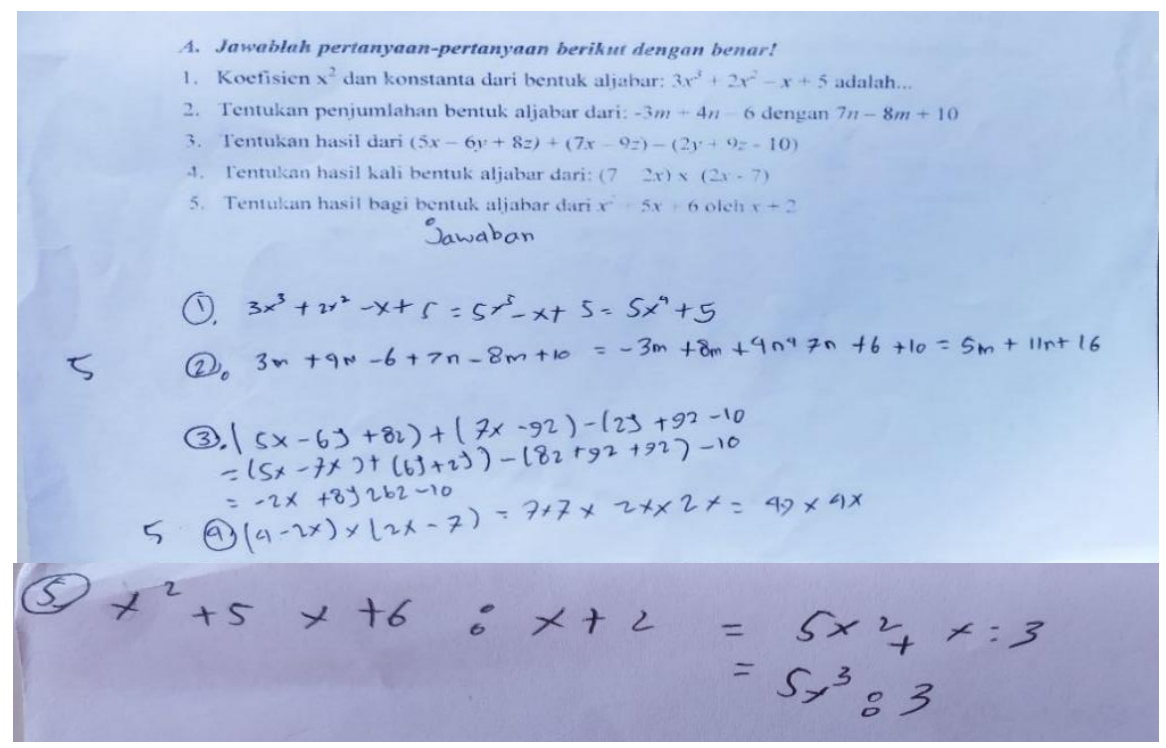

Gambar 5. Kesalahan S5 dalam mengerjakan soal tes

Hasil analisis dari jawaban S5 pada gambar 5 bahwasanya pada soal nomor 1, S5 menganggap bahwa koefisien dan konstanta merupakan suatu yang harus dicari hasilnya. S5 juga menganggap semua suku yang mengandung variabel $\mathrm{x}$ dapat langsung dijumlahkan tanpa memperhatikan pangkat variabel setiap sukunya.

Tabel 5. Kesalahan dan penyebabnya pada kasus S5

\begin{tabular}{|c|c|c|}
\hline $\begin{array}{l}\text { No. } \\
\text { Soal }\end{array}$ & Kesalahan & Indikasi kesalahan \\
\hline \multirow[t]{3}{*}{1} & kesalahan data & $\begin{array}{l}\text { menganggap pangkat pada setiap suku } \\
\text { yang sama tidak penting }\end{array}$ \\
\hline & kesalahan teknis & $\begin{array}{l}\text { menganggap koefisien dan konstanta } \\
\text { merupakan suatu yang harus dicari } \\
\text { hasilnya }\end{array}$ \\
\hline & kesalahan teorema atau definisi & $\begin{array}{l}\text { tidak memahami definisi variabel } \\
\text { koefisien konstanta dalam operasi bentuk } \\
\text { aljabar }\end{array}$ \\
\hline \multirow[t]{2}{*}{2} & kesalahan teknis & salah perhitungan \\
\hline & kesalahan data & $\begin{array}{l}\text { kesalahan dalam memindahkan tanda "_." } \\
\text { dan "+" pada operasi bentuk aljabar }\end{array}$ \\
\hline \multirow[t]{2}{*}{3} & kesalahan teknis & salah perhitungan \\
\hline & kesalahan data & $\begin{array}{l}\text { kesalahan dalam mengelompokkan data } \\
\text { dan kesalahan meletakkan tanda "_" dan } \\
\text { "+" pada operasi bentuk aljabar }\end{array}$ \\
\hline 4 & kesalahan teknis & $\begin{array}{l}\text { tidak memahami konsep perkalian bentuk } \\
\text { aljabar }\end{array}$ \\
\hline
\end{tabular}




\begin{tabular}{lll}
\hline & $\begin{array}{r}(7-2 x) \times(2 x-7)=7 \times 7 \times 2 \times 12 x \\
=49 \times 4 x\end{array}$ \\
\hline 5 kesalahan teknis & $\begin{array}{l}\text { tidak memahami konsep pembagian } \\
\text { bentuk aljabar }\end{array}$
\end{tabular}

\section{Kasus S6}

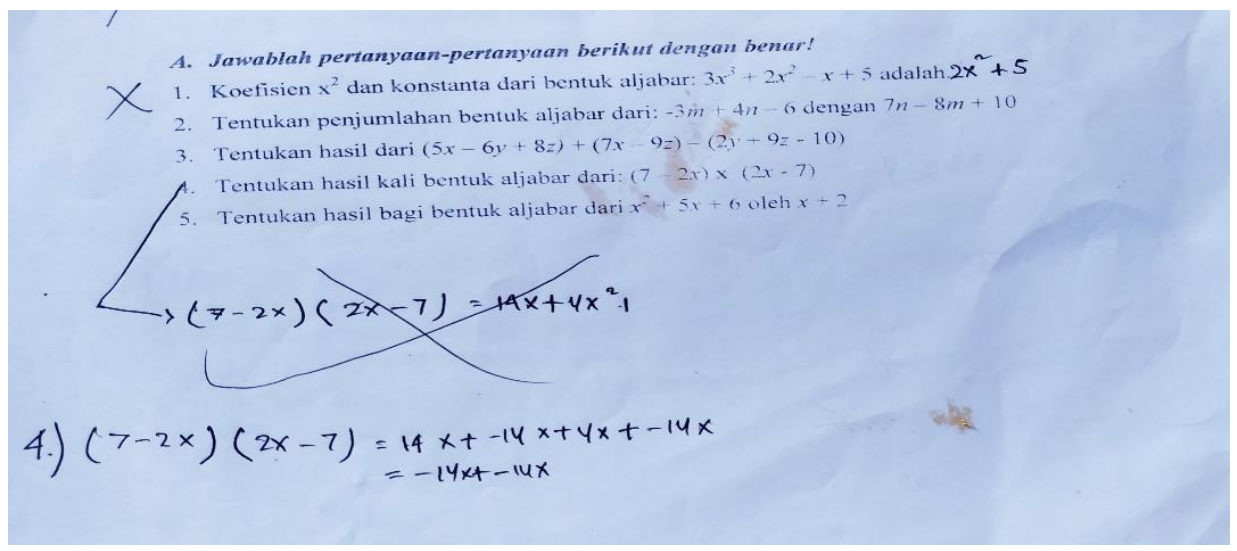

Gambar 6. Kesalahan S6 dalam mengerjakan soal tes

Hasil analisis dari jawaban S6 pada gambar 6 bahwasanya kesalahan S6 menjawab soal nomor 1 karena salah menempatkan tanda "+".

Tabel 6. Kesalahan dan penyebabnya pada kasus S6

\begin{tabular}{|c|c|c|}
\hline $\begin{array}{l}\text { No. } \\
\text { Soal }\end{array}$ & Kesalahan & Indikasi kesalahan \\
\hline \multirow[t]{2}{*}{1} & kesalahan data & $\begin{array}{l}\text { menambahkan data yang tidak ada } \\
\text { hubungannya dengan soal }\end{array}$ \\
\hline & kesalahan teknis & $\begin{array}{l}\text { mengganti jawaban yang seharusnya "dan" } \\
\text { dengan tanda "+" }\end{array}$ \\
\hline \multirow[t]{2}{*}{2} & kesalahan teknis & tidak menjawab soal tes \\
\hline & tidak memahami maksud soal & $\begin{array}{l}\text { tidak menguasai konsep penjumlahan } \\
\text { operasi bentuk aljabar }\end{array}$ \\
\hline \multirow[t]{2}{*}{3} & kesalahan teknis & tidak menjawab soal tes \\
\hline & tidak memahami maksud soal & $\begin{array}{l}\text { tidak menguasai konsep penjumlahan dan } \\
\text { pengurangan bentuk aljabar }\end{array}$ \\
\hline \multirow[t]{2}{*}{4} & kesalahan teknis & salah perhitungan \\
\hline & tidak memahami maksud soal & $\begin{array}{l}\text { mengalikan bentuk aljabar tidak sesuai } \\
\text { urutan }\end{array}$ \\
\hline 5 & kesalahan teknis & tidak menjawab soal tes \\
\hline
\end{tabular}




\section{Kasus S7}
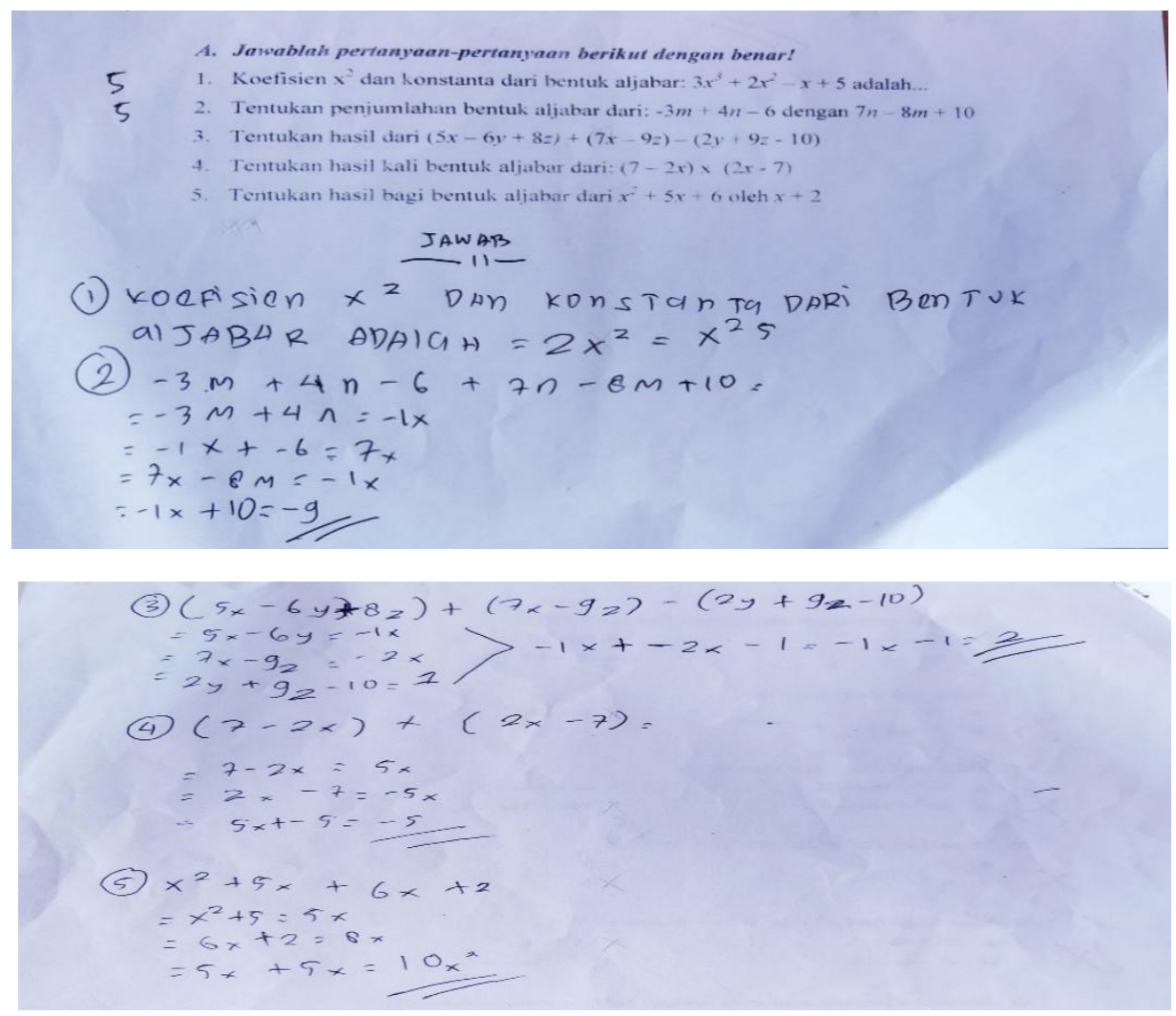

Gambar 7. Kesalahan S7 dalam mengerjakan soal tes

Hasil analisis dari jawaban S7 pada gambar 7 bahwasanya S7 menjawab soal tes dengan asal-asalan.

Tabel 7. Kesalahan dan penyebabnya pada kasus S7

\begin{tabular}{|c|c|c|}
\hline $\begin{array}{l}\text { No. } \\
\text { Soal }\end{array}$ & Kesalahan & Indikasi kesalahan \\
\hline \multirow[t]{3}{*}{1} & kesalahan data & $\begin{array}{l}\text { menjawab soal tidak sesuai dengan konsep } \\
\text { yang benar }\end{array}$ \\
\hline & kesalahan teknis & $\begin{array}{l}\text { menganggap koefisien dan konstanta } \\
\text { merupakan suatu yang harus dicari hasilnya }\end{array}$ \\
\hline & $\begin{array}{lll}\begin{array}{l}\text { kesalahan } \\
\text { definisi }\end{array} & \text { teorema atau } \\
\end{array}$ & $\begin{array}{l}\text { tidak memahami definisi variabel, koefisien, } \\
\text { dan konstanta dalam operasi bentuk aljabar }\end{array}$ \\
\hline \multirow[t]{3}{*}{2} & kesalahan teknis & $\begin{array}{l}\begin{array}{l}\text { menjawab soal tes dengan konsepnya } \\
\text { sendiri }\end{array} \\
\text { S }\end{array}$ \\
\hline & tidak memahami maksud soal & $\begin{array}{l}\text { tidak menguasai konsep penjumlahan pada } \\
\text { operasi bentuk aljabar }\end{array}$ \\
\hline & kesalahan data & $\begin{array}{l}\text { menjumlahkan suku-suku yang memiliki } \\
\text { variabel berbeda }\end{array}$ \\
\hline \multirow[t]{2}{*}{3} & kesalahan teknis & $\begin{array}{l}\text { menjawab soal tes dengan konsep yang } \\
\text { berbeda }\end{array}$ \\
\hline & tidak memahami maksud soal & $\begin{array}{l}\text { tidak menguasai konsep penjumlahan dan } \\
\text { pengurangan pada operasi bentuk aljabar }\end{array}$ \\
\hline
\end{tabular}




\begin{tabular}{lll}
\hline & kesalahan data & $\begin{array}{l}\text { menjumlahkan suku-suku yang memiliki } \\
\text { variabel berbeda }\end{array}$ \\
\hline 4 & kesalahan teknis & $\begin{array}{l}\text { menjawab soal tes dengan konsep yang } \\
\text { berbeda }\end{array}$ \\
\cline { 2 - 4 } & tidak memahami maksud soal & $\begin{array}{l}\text { tidak menguasai konsep perkalian pada } \\
\text { operasi bentuk aljabar }\end{array}$ \\
\cline { 2 - 4 } & kesalahan data & $\begin{array}{l}\text { menjumlahkan suku-suku yang memiliki } \\
\text { variabel berbeda }\end{array}$ \\
\hline 5 & kesalahan teknis & $\begin{array}{l}\text { menjawab soal tes dengan konsep yang } \\
\text { berbeda }\end{array}$ \\
\cline { 2 - 4 } & tidak memahami maksud soal & $\begin{array}{l}\text { tidak menguasai konsep pembagian pada } \\
\text { operasi bentuk aljabar }\end{array}$ \\
\cline { 2 - 4 } & kesalahan data & $\begin{array}{l}\text { menjumlahkan suku-suku yang memiliki } \\
\text { variabel berbeda }\end{array}$ \\
\hline
\end{tabular}

\section{Kasus S8}
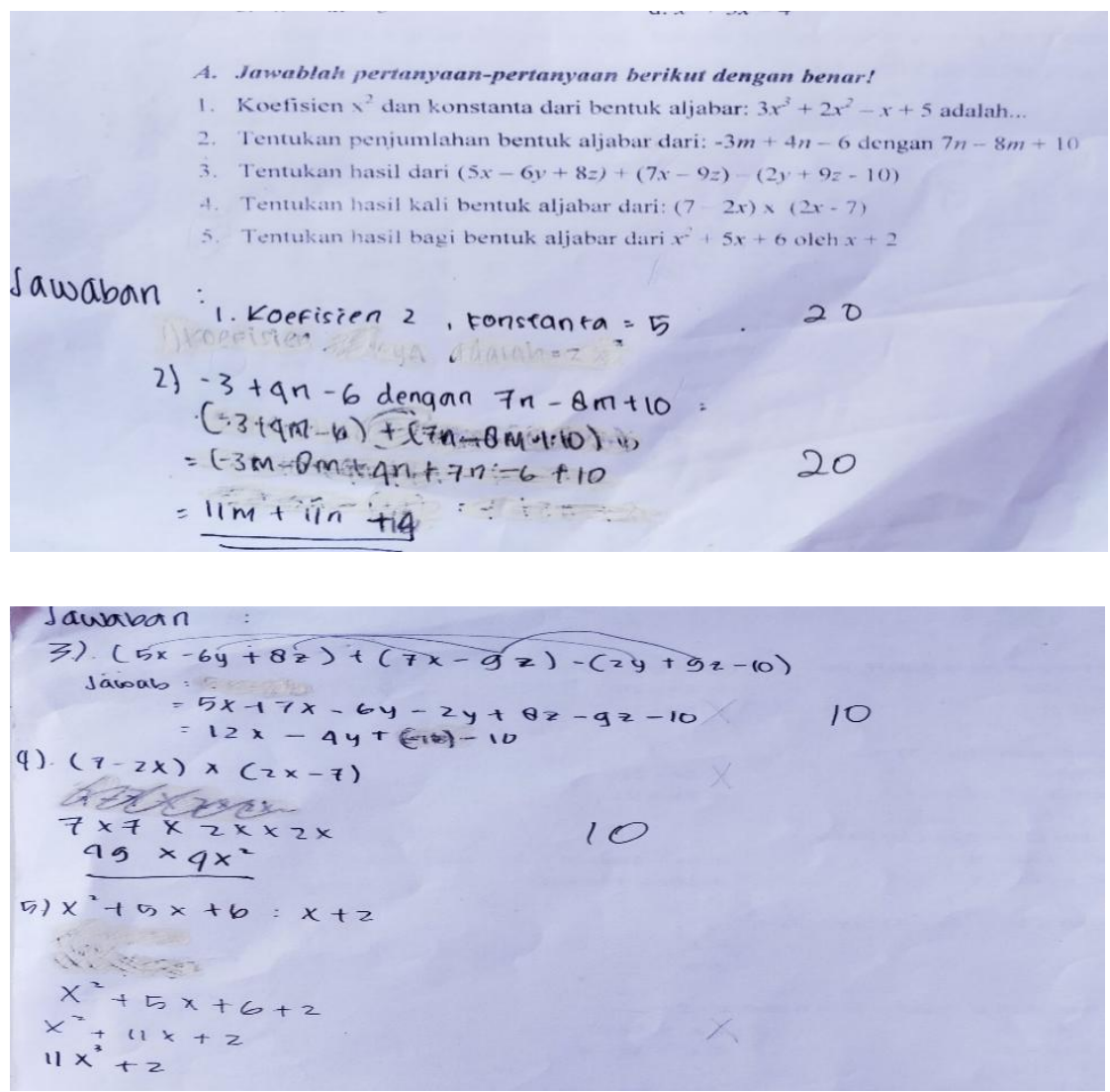

Gambar 8. Kesalahan S8 dalam mengerjakan soal tes

Hasil analisis dari jawaban S8 pada gambar 8 bahwasanya S8 telah memiliki pemahaman konsep operasi bentuk aljabar yang baik, hanya saja S8 melakukan kesalahan teknis pada hasil penghitungan. 
Tabel 8. Kesalahan dan penyebabnya pada kasus $\mathrm{S} 8$

\begin{tabular}{cll}
\hline $\begin{array}{c}\text { No. } \\
\text { Soal }\end{array}$ & \multicolumn{1}{c}{ Kesalahan } & \multicolumn{1}{c}{ Indikasi kesalahan } \\
\hline 3 & kesalahan teknis & kesalahan pada hasil perhitungan \\
\hline 4 & kesalahan teknis & $\begin{array}{l}\text { tidak memahami konsep perkalian bentuk } \\
\text { aljabar } \\
(7-2 x) \times(2 x-7)=7 \times 7 \times 2 x \times 2 x \\
\end{array}$ \\
\cline { 2 - 3 } & tidak memahami maksud soal & $\begin{array}{l}\text { tidak menguasai konsep perkalian pada } \\
\text { operasi bentuk aljabar }\end{array}$ \\
\cline { 2 - 3 } & kesalahan data & mengalikan suku-suku sejenis \\
\hline 5 & kesalahan teknis & $\begin{array}{l}\text { kesalahan dalam konsep pembagian operasi } \\
\text { bentuk aljabar }\end{array}$ \\
\cline { 2 - 3 } & tidak memahami maksud soal & $\begin{array}{l}\text { tidak menguasai konsep pembagian pada } \\
\text { operasi bentuk aljabar }\end{array}$ \\
\hline
\end{tabular}

\section{Kasus S9}

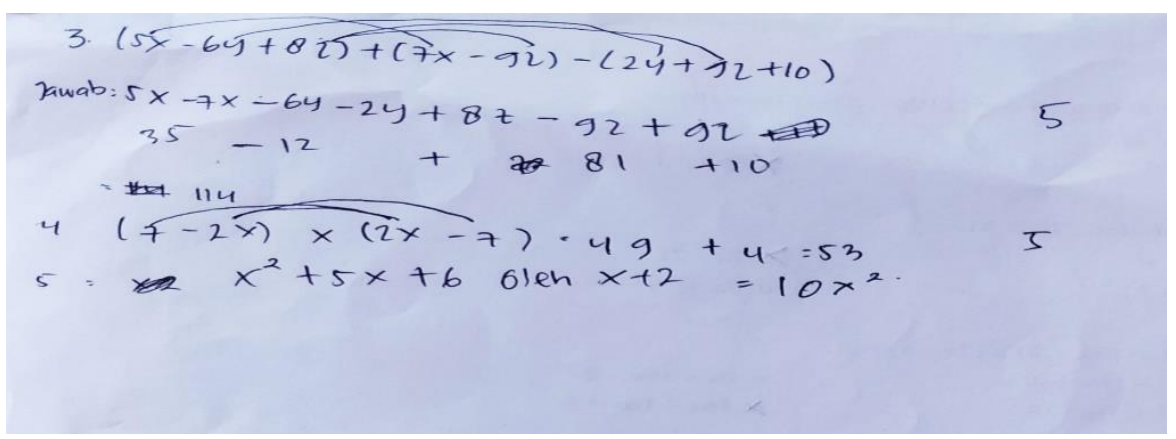

Gambar 9. Kesalahan S9 dalam mengerjakan soal tes

Hasil analisis dari jawaban S9 pada gambar 9 bahwasanya pada nomor 1, S9 menganggap koefisien sama dengan konstanta.

Tabel 9. Kesalahan dan penyebabnya pada kasus S9

\begin{tabular}{cll}
\hline $\begin{array}{c}\text { No. } \\
\text { Soal }\end{array}$ & \multicolumn{1}{c}{ Kesalahan } & \multicolumn{3}{c}{ Indikasi kesalahan } \\
\hline 1 & kesalahan data & $\begin{array}{l}\text { menganggap koefisien dan konstanta } \\
\text { adalah sama }\end{array}$ \\
\cline { 2 - 4 } & kesalahan teorema atau definisi & $\begin{array}{l}\text { tidak memahami definisi variabel, } \\
\text { koefisien, dan konstanta dalam operasi } \\
\text { bentuk aljabar }\end{array}$ \\
\hline 2 & kesalahan teknis & kesalahan dalam perhitungan \\
\cline { 2 - 4 } & kesalahan data & $\begin{array}{l}\text { kesalahan dalam menempatkan tanda "-" } \\
\text { dan "+" pada operasi bentuk aljabar }\end{array}$ \\
\hline 3 & kesalahan data & $\begin{array}{l}\text { menjawab soal tidak sesuai dengan konsep } \\
\text { yang benar }\end{array}$ \\
\cline { 2 - 4 } & kesalahan teknis & kesalahan dalam perhitungan \\
\hline 4 & kesalahan teknis & tidak memahami konsep perkalian bentuk \\
\hline
\end{tabular}




\begin{tabular}{lll}
\hline & & $\begin{array}{l}\text { aljabar } \\
(7-2 x) \times(2 x-7)=7 \times 7 \times 2 x \times 2 x \\
=49 \times 4 x\end{array}$ \\
\cline { 2 - 3 } & tidak memahami maksud soal & $\begin{array}{l}\text { tidak menguasai konsep perkalian pada } \\
\text { operasi bentuk aljabar }\end{array}$ \\
\hline 5 & kesalahan data & $\begin{array}{l}\text { menjawab soal tidak sesuai dengan konsep } \\
\text { yang benar }\end{array}$ \\
\cline { 2 - 3 } & kesalahan teknis & kesalahan dalam perhitungan \\
\hline
\end{tabular}

Semua kesalahan-kesalahan siswa dalam mengerjakan soal operasi bentuk aljabar dapat dikelompokkan sesuai kategori. Berdasarkan hasil analisis di atas, kesalahan-kesalahan yang ditemukan pada siswa kelas VII dalam mengerjakan soal matematika pada topik operasi bentuk aljabar adalah kesalahan teorema atau definisi, kesalahan data, dan kesalahan teknis. Jenis kesalahan yang banyak dilakukan siswa adalah jenis kesalahan teorema atau definisi dan kesalahan teknis.

Menurut Suparno (1997) pengalaman kita yang terbatas akan sangat membatasi perkembangan pembentukan pengetahuan kita pula. Pernyataan tersebut sesuai dengan jenis kesalahan siswa kelas VII saat diberikan soal mengenai operasi bentuk aljabar. Siswa kurang berlatih dalam menyelesaikan soal-soal tentang operasi bentuk aljabar, sehingga ketika diberikan soal tentang operasi bentuk aljabar siswa mengalami kesulitan dalam pengerjaan. Hal ini disebabkan saat siswa mengerjakan soal tentang operasi bentuk aljabar, siswa membatasi pengetahuan mereka. Operasi hitung pada bilangan bulat mempengaruhi pengetahuan siswa bahwa operasi hitung pada bilangan bulat tidak bisa digunakan dalam mengerjakan soal tentang operasi pada bentuk aljabar.

Ketidaktelitian siswa dalam menghitung operasi bilangan bulat juga menjadi salah satu faktor penyebab kesalahan yang dilakukan siswa kelas VII SMP Negeri 21 Kota Bengkulu dalam mengerjakan soal pada materi operasi bentuk aljabar. Siswa sudah memahami menghitung operasi bilangan bulat tetapi karena ketidaktelitian siswa, pekerjaannya menjadi kurang tepat. Ketidaktelitian siswa disebabkan oleh siswa malas untuk meneliti kembali hasil pekerjaannya dari awal dan ada siswa yang sudah ingin cepat selesai karena temannya sudah selesai. Siswa yang sudah selesai cenderung mengganggu temannya, salah satunya dengan mengajak berbicara. Menurut Koestoer dalam Mulyadi (2010), seorang yang mengalami kesulitan belajar dalam suatu bidang tertentu dikarenakan ada bagian-bagian dalan urutan belajar yang belum dipahami.

Kelemahan penelitian ini adalah jadwal penelitian yang bertepatan dengan terjadinya pandemi COVID-19, menyebabkan tidak dapat bertatap muka dengan objek penelitian secara langsung karena sekolah diliburkan dan larangan keluar rumah, sehingga tidak dapat dilakukan wawancara langsung kepada siswa yang menjadi objek penelitian.

Hasil penelitian ini hampir serupa dengan penelitian Dellani (2016) bahwa jenis-jenis kesalahan yang dilakukan oleh siswa kelas VIII B SMP Pangudi Luhur 1 Klaten Yogyakarta dikelompokkan menjadi 3 jenis yaitu kesalahan data, kesalahan teorema atau definisi dan kesalahan teknis. Jadwal wawancara terhadap subjek penelitian cukup jauh dengan tes diagnostik, karena kondisi yang tidak memungkinkan, sehingga subjek lupa dengan jawabannya. 


\section{SIMPULAN DAN SARAN}

Berdasarkan data analisis, maka kesalahan-kesalahan pada materi operasi bentuk aljabar yang dilakukan oleh siswa, yaitu: (1) kesalahan teorema atau definisi, (2) kesalahan teknis, (3) kesalahan data. Indikator kesalahan yang dilakukan oleh siswa, yaitu: (1) tidak memahami definisi variabel, koefisien, dan konstanta dalam operasi bentuk aljabar, (2) kurang memahami konsep penjumlahan, pengurangan, perkalian dan pembagian pada topik operasi bentuk aljabar, (3) kurangnya ketelitian dalam menempatkan tanda "_" dan "+" pada topik operasi bentuk aljabar, (4) kesalahan perhitungan saat menjumlahkan, mengurangkan, mengalikan atau membagikan bilangan pada topik operasi bentuk aljabar.

\section{DAFTAR PUSTAKA}

Arigiyati, T.A. 2017. Pengaruh Minat dan Perhatian Orang tua Terhadap Prestasi Belajar Matematika Siswa SMP. Transformasi-Jurnal Pendidikan Matematika \& Matematika, Vol. 1(1) : 27-35.

Astini, N.W. dan Purwati, N.K.R. 2020. Strategi Pembelajaran Matematika Berdasarkan Karakteristik Siswa Sekolah Dasar. Jurnal Emasains: Jurnal Edukasi Matematika dan Sains, Vol. IX(1) : 1-8.

BSNP. 2006. Permendiknas RI No.22 Tahun 2006 Tentang Standar Isi Untuk Satuan Pendidikan Dasar dan Menengah. Jakarta.

Dellani, N.M. 2016. Analisis Kesalahan Siswa dalam Mengerjakan Soal-soal Pada Topik Operasi Bentuk Aljabar Kelas VIII B SMP Pangudi Luhur 1 Klaten Tahun Ajaran 2015/2016. Skripsi tidak diterbitkan. Yogyakarta: Universitas Sanata Dharma.

Fidayanti, M., Shodiqin, A., dan Suyitno, Y.P. 2020. Analisis Kesulitan dalam Pembelajaran Matematika Materi Pecahan. Journal for Lesson and Learning Studies, Vol. 3(1) : 88-96.

Kamarullah. 2017. Pendidikan Matematika di Sekolah Kita. Al Khawarizmi, Vol. $1(1): 21-32$.

Komalasari, K. 2013. Pembelajaran Kontekstual: Konsep dan Aplikasi. Bandung: PT Refika Adiatama.

Mengapa Matematika Dianggap Sulit? Media Online Kompasiana, 18 Juni 2015.

Mulyadi. 2010. Diagnosis Kesulitan Belajar dan Bimbingan Terhadap Kesulitan Belajar Khusus. Yogyakarta: Nuha Litera.

Mustikasari, M., Isnani, dan Susongko, P. 2017. Keefektifan Model Pembelajaran Talking Stick Berbantu Media Microsoft Power Point Terhadap Prestasi Belajar Matematika Ditinjau dari Kemampuan Numerik Materi Pokok Statistika. Jurnal Pendidikan MIPA Pancasakti, Vo. 1(1) : 65-71.

Setiawan, B. 2011. Meningkatkan Kemampuan Koneksi dan Pemecahan Masalah Matematik Siswa melalui Pembelajaran Kooperatif Model Cooperative Integreted Reading and Composition (CIRC). Tesis tidak diterbitkan. Bandung: Sekolah Pascasarjana Universitas Pendidikan Indonesia.

Sugiyono. 2013. Metode Penelitian Kualitatif dan R \& D. Bandung: Alfabeta.

Suparno, P. 1997. Filsafat Konstruktivisme dalam Pendidikan. Yogyakarta: Kanisinus. 